\title{
From Age-Sets to Friendship Networks in Comparative Sociology: The continuity of soda among the Boorana of East Africa
}

\author{
Mario I. Aguilar \\ University of St. Andrews, Scotland \\ Email:mia2@st-andrews.ac.uk \\ Received June $4^{\text {th }}, 2010$; revised July $9^{\text {th }}, 2010$; accepted August $12^{\text {th }}, 2010$.
}

\begin{abstract}
This paper re-assesses a comparative sociology of kinship and friendship in East Africa with a particular focus on the Boorana Oromo of Kenya. It argues that the study of kinship dominated the developments of a comparative sociology during colonial times and that the post-colonial influences of war, the market and globalization have increased the role of the individual. As a result a comparative sociology of African kinship needs to be understood in relation to comparative sociological studies of friendship in East Africa, particularly associated with the sociology of education.
\end{abstract}

Keywords: Develop Sociological Models and Methods, Foster Interdisciplinary, Promote Analytical Research and Inquiry in Socio-Cultural Aspects, Sociological Inquiry and Research

\section{Introduction}

The field of African social anthropology could be classified as a comparative sociology and this paper deals precisely with kinship as a comparative kinship in a sociological manner. Within the anthropological study of kinship and friendship there is always the danger of stressing anthropological fashions. Thus, from the beginnings of social anthropology as a contemporary research methodology, kinship was overstressed to the effect that, by the late 1980 s, critics of kinship studies as an isolated subject associated its study with early approaches to social anthropology such as functionalism. Within the intellectual parameters posed by the functionalists, societies functioned as bodies, self-contained with parts that were interrelated. ${ }^{1}$ However, critiques of such an understanding of society and of kinship as self-contained studies misunderstood the complex processes of change within those 'self-contained societies', forgetting the importance of the comparative method previously forgotten also by the functionalists, a point already suggested by Radcliffe-Brown in his 1951 Huxley Lecture (RadcliffeBrown, 1951). ${ }^{2}$

If later anthropologists expressed their scepticism concerning

\footnotetext{
1 "The functionalists insisted upon the inner understanding that comes from participant observation because they believed that they were studying systems of organization which performed a purpose, and that both the systemic character and the meaning could be comprehended only by grasping how the system worked, from the point of view of a participant" (Kuper, 1983: 197).

${ }^{2}$ Radcliffe-Brown had previously argued that "applied to human societies the comparative method used as an instrument for inductive inference will enable us to discover the universal, essential characters which belong to all human societies, past, present, and future" (Radcliffe-Brown, 1958: xi). I have returned to the study of Radcliffe-Brown not because I agree with most of his propositions, but because such presuppositions have permeated for many years not only the study of kinship within a social body, but the task of the ethnographer that during fieldwork has tried to understand society as a collective body and social facts as manifestations of such a body.
}

the possibilities of a comparative method, they, nevertheless, used comparison in relation to social metaphors. Thus, anthropologists used social metaphors such as kinship, marriage, religion, or witchcraft in order to analyse social experiences within different societies. Most importantly for our current discussion "a central metaphor in theory articulates a range of related metaphors, so that the very way we perceive our subject matter is subtly shaped by that core metaphor" (Parkin, 1987: 53).

However, if anthropologists can discard dead metaphors as dead epistemological tools, social actors that we encounter during fieldwork cannot be discarded. Thus, at times "folk thinking contradicts professional epistemology" (Parkin, 1987: $55)$, so that if kinship as a metaphor of social relations within a group can be considered a dead epistemological tool by contemporary anthropologists, it still remains a central social metaphor of discourse within African societies (Holy, 1996; Lewis, 1994). ${ }^{3}$ When Africans prefer to speak about kin relations rather than friendship, kinship remains the opening metaphor for societal discourse and friendship follows as a possible epistemological tool used by the ethnographer.

Moreover, kinship as a social category ${ }^{4}$ is the mirror of friendship, socially constructed, always changing, however, giving away further characteristics of how human groups interact, and how groups within such larger human configurations ally themselves in order to experience humanness together. Therefore, what has been said about the study of kinship is relevant for the ongoing study of friendship, i.e. such a study cannot take place in isolation, but through ethnographic comparisons and by suggesting an ongoing change in what ethnographers could perceive as static social structures that - when fragmented - can never be studied again. ${ }^{5}$

In such a manner, the contemporary study of friendship can also become a fashionable subject, without the exclusion of

\footnotetext{
${ }^{3}$ For Europe, see Edwards (2000)

${ }^{4}$ Kinship is understood within this paper as "a culturally specific notion of relatedness deriving from shared bodily and/or spiritual substance and its transmission" (Holy, 1996: 171).
} 
kinship as a social mirror, but with the inclusion of a rethinking process asking why such a dyadic process enriches our understanding of contemporary society, be it in Africa or elsewhere. Further, and within such a contemporary anthropological investtigation, it is important to stress the centrality of the comparative method, not in terms of what it was fifty years ago, but in terms of the relation of structure and agency (Holy, 1987: 18). If kinship represents a social structure within social anthropological studies, friendship represents the agency of social actors that are still socially contained within cultural representations. Moreover, friendship constitutes a useful tool in order to understand any African social organisation in which localised groups seem to be more influenced by national and international trends than in the past.

It can be suggested that friendship as a vehicle of social association has been understudied even during periods of intense external pressure on small societies such as the colonial period in East Africa. ${ }^{6}$ In fact, the study by Wilson of Nyakyusa age-villages stressing the value placed on the "enjoyment of good company" (ukwangala) and on "mutual aid and sympathy which spring from personal friendship" (Wilson, 1951: 66), and Gulliver's description of co-operation between cousins among the Ndendeuli (Tanzania, 1971: 116-117) stand as two isolated cases among the few case studies of friendship in East Africa. Further attempts by Gulliver to study friendship in Ndendeuli were not successful because it was hard for him to isolate proper distinctions between 'friend' and 'visitor' (Gulliver, 1971: 301).

In this paper, which follows my previous study on friendship among Boorana high school students (Aguilar, 1999) and attempts to expand the ethnographic study of friendship in East Africa, I propose to locate the study of African and Boorana friendship within the development of social structures of descent and alliance. In the past, the Boorana had a very strong system of kinship structured through age-sets and age-grades within a structural sociability known as the gada system (Prins, 1953: 24-34). Within the gada system, 1) political leadership was entrusted to a set of men and lasted for eight years; 2) after such a period another set of men took over the leadership; and (c) forty years after a set had been in leadership, its sons took over the political leadership while their fathers retired (Bassi, 1996: 244-255; Baxter, 1978; Bernardi, 1985: 74-93; Legesse, 1973; Van de Loo, 1991: 23-53). While the gada system is no

${ }^{5}$ Such an inherent change remains at the centre of any social structure of kinship, so that "social structure is not to be thought of as static, but as a condition of equilibrium that only persists by being continually renewed, like the chemical-physiological homeostasis of a living organism" (Radcliffe-Brown, 1958: 22).

${ }^{6}$ To this effect it has been a romantic notion that small-scale African societies were self-contained units of orderly kinship and social organisation during the colonial period. There was enormous pressure on these societies by outside forces, particularly in fields such as education and taxation, whereby the colonial system itself questioned the cultural parameters of societal understanding assumed by East African societies that were constantly at war with each other, far from a peaceful condition of non-ethnic interaction (Baxter, 1994; Reyna, 1990). Indeed, the main threat posed by colonialism was towards cultural institutions that provided social meaning for African society, so that "although in African history the colonial experience represents but a brief moment from the perspective of today, this moment is still charged and controversial, since, to say the least, it signified a new historical form and the possibility of radically new types of discourses on African traditions and cultures" (Mudimbe, 1988: 1; Mudimbe,1994: 4). longer viable within the politics that have been dominated by the nation-state for over a century, its ideology permeates relations between male and female, affines ( $\operatorname{sod} a)$ and enemies, Boorana and non-Boorana, as a social ideal. ${ }^{7}$

This paper locates the relation between kinship and friendship in a parallel stream of sociability in which the Boorana perceive the two social categories as identical, while outsiders perceive them as different. The paper's conclusions argue that: 1) if friendship is a culturally constructed category that develops through social action, any study of its social manifestations requires the methodological assumption that any research on social performances of friendship also requires a diachronic study of kinship; and 2) friendship is part of an extended social structure that allows social integration for members that have experienced dissociation.

\section{The Study of Age-Systems and Sociability in East Africa}

One of the most important foundational approaches to the study of African societies was the unfolding of classificatory patterns of social relatedness known as kinship. Thus, African societies (with their 'tribes' and their villages ${ }^{8}$ ) were perceived by anthropologists as made of different families, lineages, and kin that operated in a structured manner through different governments, and were visibly seen as political systems that, in turn, were also reinforced and given authority through organised systems of religion (e.g. Evans-Pritchard, 1940, 1951, 1956; Beattie and Lienhardt, 1975; Fortes and Evans-Pritchard, 1950; Middleton and Tait, 1958). Such ways of analysing African societies took metaphors from the biological sciences and perceived societies as organised and interrelated bodies. Bodies were communal and kin had clear conceptions of other relations that were frequently changing and adjusting throughout rites of passage, birth, marriage, and death (Turner, 1967).

In the case of East Africa, the so-called age-systems dominated the anthropological study of kinship through the production of monographs based on the passing of time and the specific leadership by age-grades within systems of kinship in societies such as Samburu and Maasai (Spencer, 1965, 1973, 1988, 1993, 1998: 131-203 for Chamus of Lake Baringo). While fashion trends within anthropological writing deemed these writings as 'functionalist', 'outdated' or 'imagined', by the late twentieth century, it is within those orderly systems of kinship that one can find the social locations of friends among affines. If writings about classificatory systems of kinship seem to exclude any social intimacy, the close sociability of moran villages among the Maasai and the association of brothers and sisters among Boorana affines (soda) were ignored by anthropologists interested in urban networks and studies of social change, migration and dispersion. ${ }^{9}$ While studies of kinship in

\footnotetext{
${ }^{7}$ In relation to this social fact and within the study of pastoralism I have suggested that the Boorana perceive their identity as pastoralists even during times in which they do not possess herds due to war or famine. Pastoralists asserted their social identity in relation to memory, the imagination, and the past, mechanisms that are used in order to create a Boorana identity as the people of gada (Aguilar, 1999; Legesse, 2001). ${ }^{8}$ See Fardon (1987: 171-177) and Southall $(1970,1976)$ for an assessment of anthropological discontent with these terms.

${ }^{9} \mathrm{~A}$ review of such anthropological studies related to Africa can be found in Moore (1994).
} 
East Africa were perceived as less central to the study of social anthropology, studies of identity and ethnicity described interethnic relations and group associations as central to the understanding of contemporary social processes (e.g. Schlee, 1989, 1998).

\section{Kinship and Friendship in East Africa}

Following the ethnography of age-villages in Nyakyusa (Wilson, 1951) and Maasai (Spencer, 1988), I suggest that kinship and friendship are not opposed social categories of exclusion, but complementary realms for anthropological research. Within these ethnographic examples boys that join the same age-sets leave their fathers' households and go and live together, apart from their relatives, in order to prepare for their ritual path into adulthood. Thus, in the case of the Maasai moran, and during their meat feasts in the forest, they behave as a group of classmates or unmarried friends sharing meals and feasts together and inviting unmarried girls to their celebrations (Chieni and Spencer, 1993: 163-164).

In fact, within changing processes of society formation and its continuity in East Africa, some affines can also be considered friends because members of a group that live away from a localised set of social ties and a structured sociability experience a degree of individual contact that can be compared to those idealised parameters of free choice encompassed by Western existentialism and contemporary individualism. Within European social notions, individualism "pertains to a particular historico-cultural conceptualisation of the person or self and might include: notions of the ultimate value and dignity of the human individual, his or her moral and intellectual autonomy, rationality and self-knowledge, spirituality, voluntary contracting into a society, market and polity, the right to privacy and self-development" (Rapport, 1996: 298, 1993, 1997). Moreover, while any universal human self is socially constituted, the post-modernist accusation of anthropological cloning, i.e. the reproduction of social individuals with the same social characteristics is to be disregarded in the African case.

As a result of such an individuality assigned to social actors one can observe that there is, on the one hand, a direct relation between proximity to home and strong kinship ties, and distancing and friendship ties on the other. A working equation would be as follows, home: kinship - away: friendship. Within this social opposition a linear progression of kinship intensity and friendship intimacy can be observed, so that there is no structural opposition, but a social complementary, whereby individuals choose the intensity of their social affiliation, always remembering their social, ritual and economic obligations towards home. As a result, and within a dispersion of ethnic groups throughout new locations, be they in Africa or elsewhere, kinship ties can carry with them some kind of social intimacy associated with Western understandings of friendship, and can be perceived as a distinctive way of socialising with fewer individuals within societies where social actors are guests or outsiders.

The case of the Boorana (as part of a larger Oromo-speaking Diaspora) suggests that social relations of kin and friends extend throughout East African countries and beyond, including Europe, North America, and Australia (Bulcha, 2002; Zitelmann, 1994). However, these relations cannot be considered solely the product of a process of post-coloniality and social fragmentation. They were in existence within a pre-colonial system of a ritual and a political federal system, in which those associated by kinship met at ritual public moments, while groups of friends based on clear divisions of descent became part of smaller social groups that shared the same activities and aspirations through lines of generational interests, alliances, and commitments (Bahrey, 1954; Haberland, 1963). There was intermarriage as well as conflict and a full economic exchange, particularly among Boorana pastoralists with other groups such as Somali in eastern Ethiopia and eastern Kenya (Dalleo, 1975).

\section{Becoming soda in Boorana}

The Boorana are part of an extensive federation of Oromospeaking peoples that reside within the contemporary political borders of Ethiopia and Kenya. ${ }^{10}$ According to their myth of origin, the Boorana were the first of the Oromo and they encountered a messenger from God, their first qallu ('king, priest, leader') who was found in southern Ethiopia. Those present on his arrival gave him coffee beans taken from the coffee trees and offered him a maid as his spouse (Kidane, 2002: 155). Later on, the sons of the first qallu became ritual leaders of the two Boorana moieties Gona and Sabo, so that all Boorana belong to either of these moieties that have a separate qallu who individually look after a localised territory. The qallu do not leave their ritual location, but Boorana themselves visit them in order to request blessings for them, their families, and their cattle (Knutsson, 1967).

Within the history of East Africa, the Boorana acquired horses and therefore had an advantage over all other fighting groups in Ethiopia and Kenya (Oba, 1996). Boorana horsemen helped to conquer southern Ethiopia and led a military expansion that was backed by a myth of origin (the arrival of the qallu), ritual leaders (qallu) and a social and political organisation based on an age-system known as the gada system (Lewis, 1966). Within that system, age-sets formed by those initiated together were constituted every eight years in the context of a national ritual festival presided by ritual officers empowered by the qallu. Thus, every eight years, 1) Boorana males were initiated, exactly forty years after their fathers were; and 2) the age-set that had taken over political leadership ceased to be in that role and left the leadership to the next age-set that had been initiated together and had become a particular age-grade. ${ }^{11}$ As in the case of the Maasai, the system of age-grades provided at all times a group of fighting men and a group of praying men that blessed the warriors and their efforts of military defence and conquest.

By the late nineteenth century, the Ethiopian Emperor Menelik II suppressed the gada system as a political system of self-determination and imposed a centralised system of taxation, education, and political appointments (Abbas, 1994; Hassen, 1990, 1999; Holcomb and Ibssa, 1990; Jalata, 1993). Nevertheless, the Boorana continued to celebrate their ritual festivals, and as recently as 1995 in northern Kenya festivals to create a grade of older men (gadamoji) were celebrated (Kassam,

\footnotetext{
${ }^{10}$ Scholars have suggested that the Oromo-speaking peoples of Ethiopia have reached over 20 million, while in north-eastern Kenya one could suggest around 200,000 people (e.g. Jalata, 1998: 2, 22-23).

${ }^{11}$ A helpful diagram can be found in Bassi (1996b: 152).
} 
1995). ${ }^{12}$ It is within such a context of hundreds of years that the Boorana continued to work out their social relations, always referring to their myth of origin and the gada system (Aguilar, 1998b). Thus, Baxter writes:

Booran have a set of rules which regulate the choice of marriage partners and which, like those which regulate the movements of individuals within generation-sets luuba and age-sets hariiya, are formal, uncompromising, logical and definite. They seem to bear the impress of philosophical thought and mesh intellectually with the organizations and rules of the lower level putative descent groups and the generation-sets system. Marriage is forbidden between girls and men whose fathers are members of the same generation-set or sequential age-sets (Baxter, 1996: 184).

It is within that gada system that Boorana identity and kinship starts to unfold, and it is within such organised passing of time that all soda found their place in relation to each other. ${ }^{13}$ Even when the gada system was an all male system, women also found a place in relation to their husbands, fathers, brothers, and sons. ${ }^{14}$ However, with the suppression of the political manifestations of gada its ritual aspects became more important. Thus, in the case of the Guji Oromo-speaking peoples of Ethiopia, as narrated by Hinnant (1978), there was by the late 1960s a basic preoccupation with the gada system, expressed through intense periods of ritual practice celebrated in single households, a social fact supported by other works on Guji and Oromo religion (Bartels, 1983; Van de Loo, 1991). Moreover, Hinnant recognises that friendship, as a social relation, existed within the Guji Oromo, however, perceiving a false dichotomy between public moments of ritual and the conviviality of the Guji household, stating that:

By January 1969, when the dry season was reaching its peak, all gada rituals ceased. People reverted to interacting as neighbours, kinsfolk, and friends. Nowhere on the local level could I find evidence of social action or social status based specifically on gada (Hinnant, 1978: 207).

It is interesting that at the same moment in time Hinnant and Baxter initiated a debate about the nature of gada that is still relevant to contemporary discussions on friendship. For Hinnant (Hinnant, 1978: 238, 241), "gada accomplishes what the elaborate, and more static, cosmologies of many other societies

\footnotetext{
${ }^{12}$ The festivals associated with older men or gadamoji have been called 'culmination ceremonies' by Baxter because, indeed, they culminate a man's life. Baxter writes: “A gaadamoji takes down his head, which includes his male tuft, and lowers his kalaacha, and enters into a condition of sanctity. Henceforth, his very presence provides a sanctuary. He must always remain "cool" and so should never show anger or lust. He should never raise his arm or his voice, and is thus prevented from herding and, effectively, from public activities" (Baxter, 1978: 175).

${ }^{13}$ Megerssa (1996) has provided an insightful and well-informed epistemological structure to Oromo thought and values under the term ayyana. However, he received such instruction from an educated Oromo who passed on the knowledge of ideas and principles to him. For most Oromo, the celebration of gada as a public festival remained the place in time where any sense of 'Oromoness', as Megerssa calls such a social unity, was indicated and actualised.

${ }^{14}$ In the past few years Oromo women have written about the role of women within gada and have challenged nationalistic organisations within Oromo that have requested women's involvement, but have left them "unrecognised and devalued" (Kumsa, 1998: 155). For purposes of kinship and descent within anthropology, all descent within gada passed through the male, while for Oromo groups associated with the land, women represented fertility and also represented mothers to all Oromo.
}

do; it makes sense of, and humanises, the universe", thus making gada into a justification for societal unity, both structurally and cognitively. For Baxter (1978: 179), instead, "gada is a dramatised philosophy or a way of acting out of a folk faith rather than an instrumental organisation. When, therefore, men grumble about its onerous demands they are grumbling, as men do everywhere, about the demands laid on them by the religious obligations they delight in honouring". ${ }^{15}$

I shall return to such a discussion of kinship, ritual, and friendship categories later, however, it suffices to say that it is such a delight in going through ritual moments together that provides the basis for life-lasting friendships among members of the same generation-sets, those who pass through the same emotional fear and delight within communal rituals of initiation and the passing of generational time. It is within that context of friends passing through stages in their lives that a highly ritualised societal practice cannot be contrasted only with ordinary daily activities of social and economic co-operation. It is precisely through those moments of intense fear and joy in ritual that kin are socially perceived and friendships are made. Thus, Hinnant seemed to have missed the point, because ritual moments among Oromo-speaking peoples are not different activeties, but they are central to the social justification for kin, friends, and generational relations. In that sense, the political suppression of gada has not meant a severance of social relations. On the contrary, it has provided a tightening of cultural identity among the Oromo, and as I will discuss later, it has provided the reinvention of friendship ties among distinct generations of Boorana in eastern Kenya.

\section{A Twentieth-Century Generational Problem}

While the Oromo-speaking peoples constitute the majority of the Ethiopian population, groups such as the Boorana and the Gabra (Tablino, 1999; Torry, 1978; Wood, 1999) reside across the border in northern Kenya. Other Oromo-speaking groups live around the rivers of eastern Kenya, namely, the Orma near the Tana River (Ensminger, 1987, 1992), and the Waso Boorana, located around the Waso Nyiro River, where I conducted fieldwork. ${ }^{16}$ It is within this small group of pastoralists that one can assess the importance of kinship and friendship as an ideological continuation from the gada system, however, within contrasting and sometimes contradictory forms of ritual and political practice.

The Waso Boorana are the descendants of a group of Boorana that, after ongoing conflicts with the Somali at the wells in Wajir, were moved by the British colonial administration to new grazing areas around the Waso Nyiro River in 1932. They, like the Orma (Kelly ,1990, 1992), quickly converted to Islam after an intense cultural interaction with the Somali, a process of 'somalisation' (Baxter, 1966; for Rendille, see Schlee, 1982). As a result the Waso Boorana adopted Somali cloths and considered themselves Muslims (Aguilar, 1995). By the 1960s, the Waso Boorana supported the Somali claim for ${ }^{15}$ In a more recent evaluation of gada as a social system Bassi has insightfully suggested that while gada is a strong symbol of unity and nationalism, "it may have multiple meanings. It manifests itself in a wide range of social phenomena, including prescriptive rules, ceremonies, rites, public offences and actual physical villages" (Bassi, 1996: 50).

${ }^{16}$ I conducted fieldwork in Garba Tulla town, Eastern Province of Kenya, from 1987 to 1990, and in 1992 (see Aguilar, 1998). 
the annexation of the Northern Frontier District (N.F.D.) into a wider Somalia against the decision by the British government to keep the N.F.D. as the seventh province of Kenya. The Waso Boorana suffered during the Somali armed struggle against Kenya (the so-called shifta war, 1963-1967) as the Somali guerrilla retreated towards Somalia and while continuing their incursions into Kenya left the Boorana subjected to the politics of the Kenyan army (Aguilar, 1996, 1997).

If 1932 marked a change in their self-perceived identity and a break with their Boorana cultural traditions, during the shifta war the Waso Boorana lost most of their animals and became impoverished pastoralists without stock. As the Waso Boorana were located in camps and their animals were killed, new cultural experiences arose among younger generations, very different experiences than those of their fathers or grandfathers. If their grandfathers had converted to Islam and saw their new identity as successful and macrocosmic, children born after 1962 only experienced poverty, dependency, and rejection by the centralised Kenyan government.

I would suggest that it was the experience of the camps that brought a change to the emphasis on kinship and cultural Boorana practices. Children who lined at the camps remembered them as safe places where they played with each other, while previously children would have been helping their mothers at the manyatta ('households') and working very hard. It was a time when they developed deep friendships with children outside their own families that continued for many years. When the Kenyan army left in 1969, the Waso Boorana found themselves in poverty and with no stock for milk, meat, or cash. However, with the arrival of non-governmental organisations and Christian churches children had access to schools and they started spending large amounts of time away from their mothers and developing close friendships in the context of local schools and during activities organised, for example, by the Garba Tulla Catholic Mission.

The particular history of the Waso Boorana affected their social life of pastoral specificity. During colonial times, towns such as Garba Tulla were administrative and commercial centres where a District Officer resided in order to supervise taxation and security. At that time and within the N.F.D., Europeans were not allowed to reside (that rule included missionaries and spouses of colonial officers). Within such trading centres, markets for cattle and postal services operated, thus creating administrative links within colonial territories. After the shifta war Garba Tulla grew into a place of residence for Boorana pastoralists with a constant influx of missionaries and the opening of two primary schools and one secondary school that, in the case of secondary school students, followed the national pattern of school entrance through a centralised system of admissions and school attendance in any part of Kenya and preferably outside their own areas of birth and upbringing.

By the 1990s, Garba Tulla had become a town where up to 5,000 people resided, particularly during the rainy season when shepherds and their herds remained close to town. Boorana lived in settlements located around the main streets named after influential older men (e.g. manyatta Dhemo named after an older man Dhemo) or after historical events (e.g. manyatta Prison named after the place where Boorana were kept as prisoners during the shifta war). Within such a contemporary existence, men moved daily from the manyatta to the town (for business, prayers, and gossip) or they moved with the herds outside Garba Tulla (for grazing). Women searched for firewood and collected water, cooked, looked after small children or worked at the schools, the Catholic mission, or the few shops within the town, cleaning or cooking. Children of school age attended school and returned to their mothers during the late afternoon, where they were expected to do small domestic chores before the evening meal. ${ }^{17}$

It is within this expanded social order that it is difficult to speak of a unified concept of friendship among the Boorana. What is clear though, is that different generations within Boorana society associated themselves through a common purpose and a common vision of things. They became friends in the same way that the different age-grades within the gada system would have been friends in the past. Thus, a common experience of life and social vision permeated groups that were not only related by some closeness in age, but that were crossing boundaries of biological age into an experience of sociability that made them enjoy each other's company and that brought them together in order to dream of new worlds and a more prosperous future for the Waso Boorana.

Therefore, if it is not possible to speak of a unified practice of friendship within Boorana, it is certainly possible to isolate groups of men into generations that shared a common experience and became friends as a result, within a cultural model where friends can quarrel very strongly among themselves, but who support each other in the context of public meetings and the ordinary decision-making moments of everyday life (Aguilar and Birch de Aguilar, 1993). The Boorana use the words jaala, hariya and fira to signify friends. In the case of fira, friendship implies a relationship of mutual assistance, whereby "you help me ... I help you" (Leus, 1995: 298; Aguilar, 1999: 174). However, the term 'friend' only covers individuals of the same sex that cannot be covered by language used for kin or descendants, so that if a male refers to a non-kin female with a sense of closeness, he refers to her as jaalto, a term used to signify a 'lover' or a 'mistress' (Leus, 1995: 471). Nevertheless, the words are not widely used by Oromo speakers within proverbs, sayings, and wise utterances (see Kidane, 2002; Leus, n.d.; Rikitu, 1992a, 1992b).

In order to include all males within social groups that can be more loosely connected than kinship groups, I have suggested that, in the context of friendship, the following generations ${ }^{18}$ can be considered groups of friends within the social and historical realities of locality at Garba Tulla town and the Waso area of eastern Kenya:

\section{The Older Generation}

Within the gada system they would have been considered holy men (gadamoji) who had the power to bless and who were on their way to God. They are the sons of those Boorana who came into the Waso area. They perceived Islam as central to

\footnotetext{
${ }^{17}$ Within traditional Boorana society women are attached to the private sphere of the home and they build houses, while men are closer to the private sphere of the herds and they manage grazing and stock.

${ }^{18} \mathrm{I}$ use the term generations not in the biological sense of people of the same age, but in the sense used by Mannheim (1952), who unhappy with the use of biological generations suggested that from their birth individuals are socially located in a social process and share a particular mode of thought and experience.
} 
Waso Boorana life and still constitute a group of older men who control the interpretation of Boorana traditions (ada Boorana) and procedures within the Boorana settlements (manyatta). Some of them had gone to the qallu in Ethiopia in order to learn about their Boorana traditions in the early 1970s and all of them wear Somali-style clothing.

\section{The Middle Generation}

The members of this group correspond to those born before or during the shifta war, who do not have any experience of life during colonial times and who were raised within a social model of survival by acquiring education in order to help the rest of the Boorana. They wear Western clothing and some of them studied at Kenyan universities. In recent years, they have become prominent in community decisions and they have linked Boorana concerns to governmental politics and the work by Catholic missionaries in Garba Tulla.

\section{The Younger Generation}

This generation is made up of Boraana born within a stable and independent Kenya, where pastoralism as a way of life has not been central to the concerns of a modern nation-state. During the past fifteen years Western donors have sponsored them in order to attend primary school in Garba Tulla and some of them have gone to boarding schools all over Kenya. In that new context of education and Western learning they have emphasised ideas of friendship within a fragmentised system of Boorana kinship.

These generations co-operate with each other, men talk and walk together, and they share more time than would be expected of kin, who in general meet at ritual moments where issues of economic exchange and social classification are at stake.

However, within such a male-centred system of kin and friends a need arises to describe other informal social groups where friendship occurs, and where there are systems of mutual economic help and emotional support within a post-colonial situation of economic survival and diversification (Dahl, 1979), religious diversification (Aguilar, 1998), dislocation, educational success, nationalism, and globalisation in general.

\section{Networks of Friendship in Boorana}

If within the gada system all links of co-operation came out of the age-grades and their respective age-sets, within contemporary Boorana society such links of friendship have been extended to several localities and to groups specified by gender and biological age, i.e. women and children.

Thus, if the spatial differentiation of gender was not previously mentioned in the literature as central to the gada system, it certainly became central to Boorana social organisation due to the conflicts and deaths that arose out of the shifta war. Following traditional patterns of pastoralist warfare, Boorana men followed their Somali counterparts and attacked government buildings within the Eastern Province of Kenya in the early 1960s. Army reprisals included the execution of males and the killing of stock. Later within the conflict, some Boorana males who had been away or in hiding did not return to the Waso area, thus creating a vacuum within a social multiplication of widows and households that were led by women, particularly older women, and that included their daughters and their grandchilddren (Aguilar, 1994b). Within such a new social order, women established links among themselves and had to go into the public sphere in order to beg help from development agencies and Christian missions.

Therefore, and as a result of historical processes, while generations of men walk and talk together, generations of women establish networks of friendship that extend beyond locality. During an ordinary day, women work and talk outside their manyatta, while men leave in the morning and usually return during the late afternoon or early evening when the herds are brought in. Networks of friendship outside Garba Tulla are established due to the encounter between women who are not kin at weddings, and men who are not kin at funerals. In a society where literacy rates are poor, women and men wait for the sound of trucks or buses in order to get letters, parcels, presents, and news, even when patterns of seasons and grazing create a separate world between men and women (with their children).

In the case of Boorana children (and Boorana youth) the impact of education within social relations cannot be underestimated. Children spend most of their time during weekdays at school and some time during weekends at the Catholic mission, where modern commodities such as videos have become part of their childhood and their worlds. While all Boorana children repeat through their play and their creativity the role models of their parents, fewer than in the past are directly involved in the herding and grazing of animals outside Garba Tulla (Aguilar, 1994a). Therefore, while there is a pastoral ideology present within social norms and practices, mothers and children know that employment and economic success for the future would come to those who have acquired secondary and college education.

It is among these educated children at schools and universities that friendship is spoken about in terms of intimacy and mutual support through letters, phone calls, and e-mails. As a result, I have no doubt that there is a direct link of social communication between youth who are shepherds in the Waso area and those who are residing in far away places such as Europe or the United States. While in the past few years I have been surprised by a number of electronic communications from some of those children I encountered during fieldwork, I could not say that the Internet has become part of ordinary sociability within Boorana society. Nevertheless, it is possible to suggest that individual isolated friendships, as known in Europe, are only part of such a chain of social communication and interaction among friends. Reasons for such an assumption lie in the perception of selfhood and economic property as communal even within contemporary schools and development offices within the Waso area, and as perceived by the Boorana, old and young, themselves.

If in Western perceptions of intimacy it is the individual self that chooses friends, companions and confidants, within African society such a choice is made instead within the parameters of sociability extending from rural to urban areas, but central to the idea of home, locality, and belonging. The Boorana choose friends within a clear kinship pattern, i.e. within the moiety of their own, that group from which they cannot marry. Further, from within their moiety they can choose to sustain a deeper relation with those that are not considered close kin, but who are usually talked about in terms of 'brothers' and 'sisters'. For 
example, during my second period of fieldwork I had a male and a female field assistant and I asked the former if he would ever consider marrying the latter, as they seemed to be very close. He replied that he could not marry her "because she was his sister". Another example was of those secondary school Boorana students from Garba Tulla who were attending school in different parts of Kenya. They corresponded by letter quite regularly and while boys addressed girls as 'sister', boys addressed other boys as 'friends', a phenomenon of kinship-friendship relatedness that was also addressed by Boorana schoolgirls in the same way (Aguilar, 1999a).

If one returns to discussions on the gada system, it is clear that all those who belonged to another ethnic group ('tribe') could not be friends (in most cases they were enemies and possible trophies for initiation purposes; see Baxter, 1979), while they became friends by economic co-operation based on changeable variables related to locality, place, and intermarriage. Therefore it is clear that such a sense of friends and friendship relates to changing patterns of mobility where Boorana communicate at a distance from their homelands to other places where other Boorana reside for educational, economic, or working reasons. It is in these situations of being far away from home that friendship among peers is stressed, and where a rediscovery of cultural friendship and its cultural centrality takes place.

The contemporary phenomenon of a Boorana Diaspora is not a new one. Boorana pastoralists used to search for water and grazing outside their home areas during colonial times and later, when movement was limited by colonial laws, men journeyed to other kin and friends in time of drought or economic hardship, and during hard times when support from elsewhere was needed. In the 1970s, for example, a group of Boorana leaders journeyed to the Boorana homelands in southern Ethiopia in order to discuss their own practice of Boorana religion with the qallu in the light of their massive conversion to Islam thirty years before. During such a journey Boorana spoke of the support they had received along the way from many kin and friends, not only for their journey, but in order to replenish the Boorana stock that had been lost through the war period.

Within such networks of Boorana friendship older men speak of Bale in southern Ethiopia as 'home' while younger Boorana refer to the Waso area as their home. Therefore, rural areas such as the Waso area and Garba Tulla in particular remain central to cultural perceptions of kinship and friendship even by those Boorana currently located as far as Germany, Ireland, or the United States. If Boorana society has ceased to exist as a localised and bounded entity, social structures and social institutions prevail, while social transformation accommodates a diversification of social interaction. Within such a diversification, studies of friendship as well as kinship tend to provide fruitful avenues for social investigation into patterns of change and continuity within the Boorana community in Kenya and, indeed, among the Oromo speaking peoples of East Africa and the globalised Diaspora.

\section{Conclusion: The importance of friends in Africa}

In his insightful discussion of friends, selves, and relationships Carrier has problematised Western notions of the self and of friendship by suggesting that:
Friendship is not just a relationship between people, it is a kind of relationship, one based on spontaneous and unconstrained sentiment or affection. After all, if the relationship is constrained we confront something very different from what we call 'friendship', something like bureaucratic relationships, kinship relationships or patron-client relationships (Carrier, 1999: 21).

My attention to the talk and the thought about friendship means I set aside the affection that people we call friends feel towards each other. I ignore it, not because I think it is unreal or unimportant, but because it is the talk and the thought that constructs as friendship the relationship in which the affection occurs, that makes it different from other relationships in which people feel affection towards each other. I see no reason to doubt that all people in all sorts of relationships can feel affecttion towards each other. But not everyone talks of the affection and the relationship as friendship (Carrier, 1999: 22).

It is symptomatic of the problematic contextualisation of the study of friendship within anthropology that Western selves, including those of anthropologists, can easily relate to Carrier's definition of friendship. However, not everybody can disentangle the emotional involvement of friends with their actions within a social system. Indeed, later in his essay Carrier (1999: 36) argues that both "the idea of friendship and of the autonomous sentimental self are cultural elements that do not exist on their own, but exist in a broader social, political and economic context". Thus, one can reiterate once again that friendship, like any other social relation, is culturally constructed. Within such a particular cultural and social context, "friendship is often perceived and valued as an affective and voluntary relationship, in which sociability and equality between friends are stressed" (Barcellos Rezende, 1996: 246).

Therefore, and in the case of Africa, friendship is not to be understood as an isolating relation between individuals; instead it must be situated and therefore studied within the realms of kinship. If in the case of Latin America friendship is overwhelmingly understood as a daily and ordinary experience of sociability, i.e. "the frequency with which the term 'friend' was used" (Barcellos Rezende, 1999: 79), in the African experience of the Boorana such daily and ordinary experience is that of affine (soda; see Baxter, 1996). In the case of the Brazilian experience, maids become part of the family and thus are described as kin, while in the Boorana experience these outside kinship systems, such as anthropologists, cannot after intense social action, be considered 'affines'. Indeed, part of the 'going native' side of fieldwork entails a successful acquisition of friends and companions, while in the case of the 'natives' it requires a clear classificatory model that relates to the anthropologist as well as to every affine. ${ }^{19}$

It is within these two examples that a system of African

\footnotetext{
${ }^{19}$ This is one of the reasons why anthropologists have noticed that their subjects of study are more relaxed towards them when they have a spouse (partner) or in the case of female anthropologists when they have had children of their own and they bring them to periods of fieldwork. See, for example, the case of Dahl and her different periods of fieldwork in Boorana. During her initial fieldwork, even when she had a husband but no children, she was treated as a 'girl' (intal). Later, when she had a child of her own she readdressed her status, while for the most part she never encountered any problems when talking to Boorana, particularly women (Dahl, 1979: 267-268; Dahl and Hjort, 1976; Hjort, 1979).
} 
friendship develops, more within a kinship system than without. Friendship presupposes social affinity and social affinity presupposes social roles within a self-contained locality of ethnic affinity. Thus, friendship requires equality within a kinship system in which social difference prevents friendship actions as social actions. Friendships arise out of kinship ties, complying with some of the characteristics of north-eastern European examples of friendship in which friends are described as "participants in a range of significant, positive, and ideally long-term personal connections" (Abrahams, 1999: 155).

Within the contemporary climate of globalised communities it would be easier to locate friendship within discussions on community and belonging. Within these discussions community "has become a way of designating that something is shared among a group of people at a time when we no longer assume that anything is necessarily shared" (Cohen, 2002: 169). Further, the whole concept of cultural belonging has been somehow challenged by suggesting that "in a post-cultural world, as we have seen, the focus is firmly upon culture as optional resource, as a trope of belonging, employed by individual actors on a global stage" (Rapport, 2002: 162).

It is within those Western critiques of cultural belonging that one could pose the unresolved problem of Western and non-Western perceptions of society and, indeed, of friendship. After all, it seems that 'cultural intimacy' (Herzfeld, 1997) requires a contextualised approach rather than a globalised one. It is within these parameters of the social practice of Boorana kinship that one encounters individual discourses and social practices related to friendship, not within outsiders' discourses on globalised individualised identities. If the study of friendship within rural African communities is taken seriously, it seems that social anthropological dyadic categories resolved within power structures of Western literacy come to be problematic once again and bring the researcher into a full cycle of investigation into friendship-kinship structures and practices, so that "assumptions about the distinctions between kinship and friendship in Euro-American contexts require some rethinking" (Reed-Danahay, 1999: 152).

Social experiences of friendship can be compared. However, what we compare are necessarily glimpses of sociability that can be misinterpreted and that do not necessarily fit into anthropological monographs by the fact that they are made into a textual reality (or nowadays a virtual reality). After all, the literary search for 'dialogical' or 'polyphonic' texts (Clifford, 1986; Marcus and Fischer, 1986) has not solved anthropological difficulties concerning the representation and production of texts (for Africa, see van Dijk and Pels, 1996). The same problem can be perceived in the use of translation, thus the perception of 'friend' for an American or a British person is different than the perception of jaala, hariya, and fira for a Boorana.

In sum, I have suggested in this paper that: 1) friendship is a social category that can be studied mostly by using the word 'friendship' as a metaphor for understanding social action within a particular society, ethnic group, community, network, or group; 2) the study of friendship remains closely linked to that of kinship understood as a set of kin relations that can have idealised and fragmented practices; and 3) the social study of friendship practices requires the study of economic and social networks such as cultural Diasporas, whereby the closer to home people are, the stronger the kinship ties are, while the farther from home they are, the stronger the friendship ties are.

\section{References}

Abbas, H. (1994). Menelik's Conquest as the Genesis of Ethiopian Crises: A case of the Arsi Oromo. The Oromo Commentary, 4, 17-23.

Abrahams, R. (1999). Friends and Networks as Survival Strategies in North-East Europe. In S. Bell and S. Coleman (Eds.). The Anthropology of Friendship (pp. 155-168). Oxford, New York: Berg.

Aguilar, M. I. (1994a). Portraying society through children: play among the waso boorana of Kenya. Anthropos, 89, 29-38.

Aguilar, M. I. (1994b). Anthropology and anomalies in kinship patterns. Anthropology in Action, 1, 25-26.

Aguilar, M. I. (1995). African Conversion from a World Religion: Religious diversification by the Waso Boorana of Kenya. Africa, 65, 525-544. doi:10.2307/1161131

Aguilar, M. I. (1996). Writing Biographies of Boorana: Social histories at the time of Kenya's independence. History in Africa, 23, 351-367. doi: $10.2307 / 3171948$

Aguilar, M. I. (1997). Historical Anthropology and Anthropological History: Rethinking the social production on an African past. In S. McGrath et al. (Eds.) Rethinking African History (pp. 357-378). Edinburgh: University of Edinburgh, Centres of African Studies.

Aguilar, M. I. (1998a). Being Oromo in Kenya. Trenton, N.J.: Africa World Press.

Aguilar, M. I. (1998b). Reinventing Gada: Generational knowledge in Boorana. In M. I. Aguilar (Ed.). The Politics of Age and Gerontocracy in Africa: Ethnographies of the past and memories of the present (pp. 257-279). Trenton, N.J.: Africa World Press.

Aguilar, M. I. (1999a). Localized Kin and Globalized Friends: Religious modernity and the 'educated self' in East Africa. In S. Bell and S. Coleman (Eds.). The Anthropology of Friendship (pp. 169-184). Oxford, New York: Berg.

Aguilar, M. I. (1999b). Pastoral Identities: Memories, memorials and imaginations in the postcoloniality of East Africa. Anthropos 94, 149-161.

Aguilar, M. I., and L. Birch de Aguilar. (1993). Women's Organizing Abilities: Two case studies in Kenya and Malawi. Washington, D.C.: ODII.

Bahrey. (1954). History of the Galla. In C.F. Beckingham and G.B.W. Huntingford (Eds.). Some Records of Ethiopia 1593-1646 (pp. 109-129). London: Hakluyt Society.

Barcellos Rezende, C. (1996). Friendship. In A. Barnard and J. Spencer (Eds.). Encyclopedia of Social and Cultural Anthropology (pp. 246). London, New York: Routledge.

Barcellos Rezende, C. (1999). Building Affinity through Friendship. In S. Bell and S. Coleman (Eds.). The Anthropology of Friendship (pp. 79-97). Oxford, New York: Berg.

Bartels, L. (1983). Oromo Religion. Myths and rites of the Western Oromo of Ethiopia: An attempt to understand. Berlin: Dietrich Reimer.

Bassi, M. (1996a). I Borana: Una società assembleare dell'Etiopia. Milano: Franco Angeli.

Bassi, M. (1996b). Power's Ambiguity or the political significance of gada. In P. T. W. Baxter, J. Hultin and A. Triulzi (Eds.). Being and Becoming Oromo: Historical and anthropological enquiries (pp. 150-161). Uppsala: Nordiska Afrikainstitutet, Lawrenceville, N.J.: The Red Sea Press.

Baxter, P. T. W. (1966). Acceptance and rejection of Islam among the Boran of the Northern Frontier District of Kenya. In I. M. Lewis (Ed.). Islam in tropical Africa (pp. 233-250). London: Oxford University Press for the International African Institute.

Baxter, P. T. W. (1978). Boran Age-Sets and Generation-Sets: Gada, a puzzle or a maze? In P.T.W. Baxter and U. Almagor (Eds.). Age, generation and time: Some features of East African age organisations (pp. 151-182). London: C. Hurst.

Baxter, P. T. W. (1979). Boran age-sets and warfare. In K. Fukui and D. 
Turton (Eds.). Warfare among East African Herders (pp. 69-95). Osaka: National Museum of Ethnology, Senri Ethnological Studies 3 .

Baxter, P. T. W. (1994). The creation and constitution of Oromo Nationality. In K. Fukui and J. Markakis (Eds.). Ethnicity and conflict in the horn of Africa (pp. 167-186). London: James Currey; Athens: Ohio University Press.

Baxter, P. T. W. (1996). Towards a comparative Ethnography of the Oromo: The importance of affines. In P. T. W. Baxter, J. Hultin and A. Triulzi (Eds.). Being and becoming Oromo: Historical and anthropological enquiries (pp. 178-189). Uppsala: Nordiska Afrikainstitutet, Lawrenceville, N.J.: The Red Sea Press.

Beattie, J. H. M., and Lienhardt, R.G. (1975). Studies in Social Anthropology: Essays in memory of E.E. Evans-Pritchard by his former Oxford colleagues. Oxford: Clarendon Press.

Bernardi, B. (1985). Age class systems: Social institutions and polities based on age. Cambridge: Cambridge University Press. doi:10.1017/CBO9780511557941

Bulcha, M. (2002). The making of the Oromo Diaspora: A historical sociology of forced migration. Minneapolis, M.N.: Kirk House.

Carrier, J. G. (1999). People who can be friends: Selves and social relationships. In S. Bell and S. Coleman (Eds.). The Anthropology of friendship (pp. 21-38). Oxford, New York: Berg.

Chieni, T., and Spencer, P. (1993). The world of Telelia: Reflections of a Maasai woman in Matapato. In T. Spear and R. Waller (Eds.). Being Maasai: Ethnicity and identity in East Africa (pp. 157-173). London: James Currey.

Clifford, J. (1986). Introduction: Partial truths. In J. Clifford and G. Marcus (Eds.). Writing culture (pp. 1-26). Berkeley: University of California Press.

Cohen, A. P. (2002). Epilogue. In V. Amit (Ed.). Realizing community: Concepts, social relationships and sentiments (pp. 165-170). London, New York: Routledge.

Dahl, G. (1979). Suffering grass: Subsistence and society of Waso Borana. Stockholm: Department of Social Anthropology, Stockholm Studies in Social Anthropology.

Dahl, G., and Hjort, A. (1976). Having herds: Pastoral herd growth and household economy. Stockholm: Department of Social Anthropology, Stockholm Studies in Social Anthropology.

Dalleo, P. (1975). Trade and pastoralism: Economic factors in the history of the Somali of Northeastern Kenya 1892-1948. Syracuse University, unpublished Ph.D. Thesis.

Edwards, J. (2000). Born and bred: Idioms of kinship and new reproductive technologies in England. Oxford, New York: Oxford University Press.

Ensminger, J. (1987). Economic and political differentiation among Galole Orma women'. Ethnos, 52 , 28-49. doi:10.1080/00141844.1987.9981334

Ensminger, J. (1992). Making a market: The institutional transformation of an African society. Cambridge: Cambridge University Press.

Evans-Pritchard, E. E. (1940). The Nuer: A description of the modes of livelihood and political institutions of a Nilotic people. Oxford: Oxford University Press.

Evans-Pritchard, E. E. (1951). Kinship and marriage among the Nuer. Oxford: Oxford University Press.

Evans-Pritchard, E. E. (1956). Nuer Religion. Oxford: Oxford University Press.

Fardon, R. (1987). African ethnogenesis: Limits to the comparability of ethnic phenomena. In L. Holy (Ed.). Comparative anthropology (pp. 168-188). Oxford: Basil Blackwell.

Fortes, M., and Evans-Pritchard, E. E. (Eds.). (1950). African political systems. London: KPI in association with the International African Institute.

Gulliver, P. H. (1971). Neighbours and networks: The idiom of kinship in social action among the Ndendeuli of Tanzania. Berkeley: University of California Press.

Haberland, E. (1963). Galla Sud-Athiopiens. Stuttgart: W. Kohlhammer.

Hassen, M. (1990). The Oromo of Ethiopia: A history 1570-1860. Cambridge: Cambridge University Press.
Hassen, M. (1999). A short history of Oromo colonial experience 1870s-1990s: Part 1 - 1870s to 1935. Journal of Oromo Studies 6, 109-158.

Herzfeld, M. (1997). Cultural intimacy: Cultural poetics in the Nation-State. New York, London: Routledge.

Hinnant, J. (1978). The Guji: Gada as a ritual system. In P.T.W. Baxter and U. Almagor (Eds.). Age, generation and time: Some features of East African age organisations (pp. 207-243). London: C. Hurst.

Hjort, A. (1979). Savanna town: Rural ties and urban opportunities in northern Kenya. Stockholm: Department of Social Anthropology, Stockholm Studies in Social Anthropology.

Holcomb, B. K., and Ibssa, S. (1990). The invention of Ethiopia: The making of a dependent colonial state in Northeast Africa. Trenton, N.J.: Red Sea Press.

Holy, L. (1987). Introduction: Description, generalization and comparison. Two paradigms. In L. Holy (Ed.). Comparative Anthropology (pp. 1-21). Oxford: Basil Blackwell.

Holy, L. (1996). Anthropological perspectives on kinship. London, Chicago: Pluto.

Jalata, A. (1993). Oromia and Ethiopia: State formation and ethnonational conflict, 1868-1992. Boulder, London: Lynne Rienner.

Jalata, A. (1998). The emergence of Oromo Nationalism and Ethiopian reaction. In A. Jalata (Ed.). Oromo Nationalism and the Ethiopian discourse: The search for freedom and democracy (pp. 1-26). Lawrenceville, N.J.: The Red Sea Press.

Kassam, A. (1995). Notes on the Booran Oromo Gadamojjii ceremony held at Sololo (Kenya), June-July 1995. The Oromo Commentary, 5, 23-24.

Kelly, H. A. (1990). Commercialization, sedentarization, economic diversification and changing property relations among Orma Pastoralists of Kenya: Some possible target issues for future pastoral research. In P. T. W. Baxter and R. Hogg (Eds.). Property, poverty and people: Changing rights in property and problems of pastoral development (pp. 80-94). Manchester: University of Manchester, Department of Social Anthropology and International Development Centre.

Kelly, H. A. (1992). From 'gada' to Islam: The moral authority of gender relations among the pastoral Orma of Kenya. University of California, Los Angeles, unpublished Ph.D. Thesis.

Kidane, S. (2002). The origin of the Qallu. In Borana folktales: A contextual study (pp. 155). London: Haan, New Brunswick: Transaction.

Knutsson, K. E. (1967). Authority and change: A study of the kallu institution among the Macha Galla of Ethiopia. Gothenburg: Museum of Ethnography, Etnologiska Studier 29.

Kumsa, K. (1998). Oromo women and the Oromo national movement: Dilemmas, problems and prospects for true liberation. In A. Jalata (Ed.). Oromo nationalism and the Ethiopian discourse: The search for freedom and democracy (pp. 153-182). Lawrenceville, N.J.: The Red Sea Press.

Kuper, A. (1983). Anthropology and Anthropologists: The modern British School. London and New York: Routledge.

Legesse, A. (1973). Gada: Three approaches to the study of African society. New York: The Free Press.

Legesse, A. (2001). Oromo democracy: An indigenous African political system. Lawrenceville, N.J.: The Red Sea Press.

Leus, T. (1995). Borana Dictionary. Sebijadel: W. S. D. Grafisch Centrum.

Leus, T. n. d. Mammaasa Booranaa. Dhadiim: Yaaballoo.

Lewis, H. S. (1966). The origins of the Galla and Somali'. Journal of African History, 7, 27-46. doi:10.1017/S0021853700006058

Lewis, I. M. (1994). Blood and bone: The call of kinship in Somali society. Lawrenceville, N.J.: The Red Sea Press.

Mannheim, K. (1952). The problem of generations. In P. Kecskemeti (Ed.). Essays on the sociology of knowledge (pp. 276-320). London: Routledge \& Kegan Paul.

Marcus, G., and Fischer M. (1986). Anthropology as Cultural Critique. Chicago: Chicago University Press.

Megerssa, G. (1996). Oromumma: Tradition, consciousness and identity. In P. T. W. Baxter, J. Hultin and A. Triulzi (Eds.). Being and 
becoming Oromo: Historical and anthropological enquiries (pp. 92-102). Uppsala: Nordiska Afrikainstitutet, Lawrenceville, N.J.: The Red Sea Press.

Middleton, J., and Tait D. (Eds.). (1958). Tribes without rulers: Studies in African segmentary systems. London: Routledge \& Kegan Paul.

Moore, S. F. (1994). Anthropology and Africa: Changing perspectives on a changing scene. Charlottesville, London: University Press of Virginia.

Mudimbe, V. Y. (1988). The invention of Africa: Gnosis, philosophy, and the order of knowledge. Bloomington, Indianapolis: Indiana University Press, London: James Currey.

Mudimbe, V. Y. (1994). The idea of Africa. Bloomington, Indianapolis: Indiana University Press, London: James Currey.

Oba, G. (1996). Shifting identities along resources borders'. In P. T. W. Baxter, H. Jan and A. Triulzi (Eds.). Being and becoming Oromo: Historical and anthropological enquiries (pp. 117-131). Uppsala: Nordiska Afrikainstitutet, Lawrenceville, N.J.: The Red Sea Press.

Parkin, D. (1987). Comparison as the search for continuity. In L. Holy (Ed.). Comparative Anthropology (pp. 52-69). Oxford: Basil Blackwell.

Prins, A. H. J. (1953). East African age-class systems: An inquiry into the social order of Galla, Kipsigis and Kikuyu. Groningen and Djakarta: J. B. Wolters.

Radcliffe-Brown. A. R. (1951). The comparative method in Social Anthropology. Journal of the Royal Anthropological Institute, 81, 15-22.

Radcliffe-Brown. A. R. (1958) [1940]. Preface. In M. Fortes and E. E. Evans-Pritchard (Eds.). African political systems. London, New York, Toronto: Oxford University Press for the International African Institute, pp. 14-23.

Rapport, N. (1993). Diverse world-views in an English village. Edinburgh: Edinburgh University Press.

Rapport, N. (1996). Individualism. In A. Barnard and J. Spencer (Eds.). Encyclopedia of social and Cultural Anthropology (pp. 298-302). London, New York: Routledge.

Rapport, N. (1997). Transcendent individual: Toward a literary and liberal anthropology. London, New York: Routledge.

Rapport, N. (2002). Post-cultural Anthropology: The ironization of values in a world of movement. In V. Amit (Ed.). Realizing community: Concepts, social relationships and sentiments (pp. 146-164). London, New York: Routledge.

Reyna, S. P. (1990). Wars without end: The political economy of a precolonial African state. Hanover: University Press of New England.

Reed-Danahay, D. (1999). Friendship, kinship and the life course in rural Auvergne. In S. Bell and S. Coleman (Eds.). The Anthropology offriendship (pp. 137-154). Oxford, New York: Berg.

Rikitu, M. (1992a). Oromo oral treasure for a new generation: Proverbs and sayings of the Oromo people with English explanation. London: Top Print.

Rikitu, M. (1992b). Oromo folk-tales for a new generation. London:
Tyndale Press.

Schlee, G. (1982). Annahme und ablehnung von Christentum and Islam bei den Rendille in Nord-Kenia. In Ostafrikanische Völker zwischen Mission und Regierung (Referate einer Arbeitskonferenz in Erlangen 16-18 Juni) (pp. 101-130). Erlangen: Copy Print.

Schlee, G. (1989). Identities on the move: Clanship and Pastoralism in Northern Kenya. Manchester: Manchester University Press.

Schlee, G. (1998). Some effects on a district boundary in Kenya. In M. I. Aguilar (Ed.). The politics of age and Gerontocracy in Africa: Ethnographies of the past and memories of the present (pp. 226-256). Trenton, N.J.: Africa World Press.

Southall, A. (1970). The illusion of tribe. Journal of African and Asian Studies, 5, 28-50. doi:10.1177/002190967000500104

Southall, A. (1976). Nuer and Dinka are people: Ecology, ethnicity and logical possibility. Man, 11, 463-491. doi:10.2307/2800433

Spencer, P. (1965). The Samburu: A study of gerontocracy in a nomadic tribe. London: Routledge \& Kegan Paul.

Spencer, P. (1973). Nomads in alliance: Symbiosis and growth among the Rendille and Samburu of Kenya. London: Oxford University Press.

Spencer, P. (1988). The Maasai of Matapato: A study of rituals of rebellion. Manchester: Manchester University Press.

Spencer, P. (1993). Becoming Maasai, being in time. In T. Spear and R. Waller (Eds.). Being Maasai: Ethnicity and identity in East Africa (pp. 140-156). London: James Currey.

Spencer, P. (1998). The pastoral continuum: The marginalization of tradition in East Africa. Oxford: Clarendon Press.

Tablino, P. (1999). The Gabra: Camel nomads of Northern Kenya. Nairobi: Paulines Publications Africa.

Torry, W. (1978). Gabra Age Organisation and Ecology'. In P. T. W. Baxter and U. Almagor (Eds.). Age, generation and time: Some features of East African age organisations (pp. 183-206). London: C. Hurst.

Turner, V. (1967). The forest of symbols: Aspects of Ndembu ritual. Ithaca, London: Cornell University Press.

Van de Loo, J. (1991). Guji Oromo Culture in Southern Ethiopia: Religious capabilities in rituals and songs [with the collaboration of Bilow Kola]. Berlin: Dietrich Reimer.

Van Dijk, R., and Pels, P. (1996). Contested authorities and the politics of perception: Deconstructing the study of religion in Africa. In R. Werbner and T. Ranger (Eds.) Postcolonial identities in Africa (pp. 245-270). London, New Jersey: Zed.

Wilson, M. (1951). Good company: A study of Nyakyusa age-villages. London: Oxford University Press for the International African Institute.

Wood, J. C. (1999). When men are women: Manhood among Gabra nomads of East Africa. Madison: University of Wisconsin Press.

Zitelmann, T. (1994). Nation der Oromo: Kollektive identitäten, nationale Konflikte, Wir-Gruppenbildungen. Berlin: Das Arabische Buch. 